\title{
FE DE ERRATAS
}

Roberto Fernández Díaz y Carlos Martínez Shaw, «La pesca en la España del siglo xviII. Una aproximación cuantitativa (1748-1765)», año II, núm. 3 (otoño 1984), pp. 183.201.

En el cuadro 4 de este artículo (p. 192) se deslizaron varios errores. A continuación publicamos el cuadro sin errores.

\section{CUADRO 4}

\begin{tabular}{|c|c|c|c|}
\hline & Multiplicador & Pescudores. & $\%$ \\
\hline $\begin{array}{llllll}\text { Galicia } & \ldots & \ldots & \ldots & \ldots & \ldots \\
\text { Cataluña } & \ldots & \ldots & \ldots & \ldots \\
\text { Andalucía } & \ldots & \ldots & \ldots & \ldots \\
\text { País Valenciano } & \ldots & \ldots \\
\text { Mallorca-Ibiza } & \ldots & \ldots & \ldots \\
\text { Asturias } & \ldots & \ldots & \ldots & \ldots & \ldots \\
\text { Murcia } & \ldots & \ldots & \ldots & \ldots & \ldots \\
\text { Mun } & \ldots & \ldots \\
\text { Santander } & \ldots & \ldots & \ldots & \ldots\end{array}$ & $\begin{array}{r}3,57 \\
3,60 \\
5.38 \\
4.48 \\
4,19 \\
2,83 \\
4,72 \\
2,80\end{array}$ & $\begin{array}{r}6.418 \\
4.654 \\
3.007 \\
1.962 \\
1.043 \\
588 \\
585 \\
462\end{array}$ & $\begin{array}{r}34,28 \\
24,86 \\
16,06 \\
10,48 \\
5,57 \\
3,14 \\
3,12 \\
2,46\end{array}$ \\
\hline TOTAL $\ldots \ldots \ldots \ldots$ & 3,87 & 18.719 & 99,97 \\
\hline
\end{tabular}

